\title{
Human uniqueness: An unfinished agenda
}

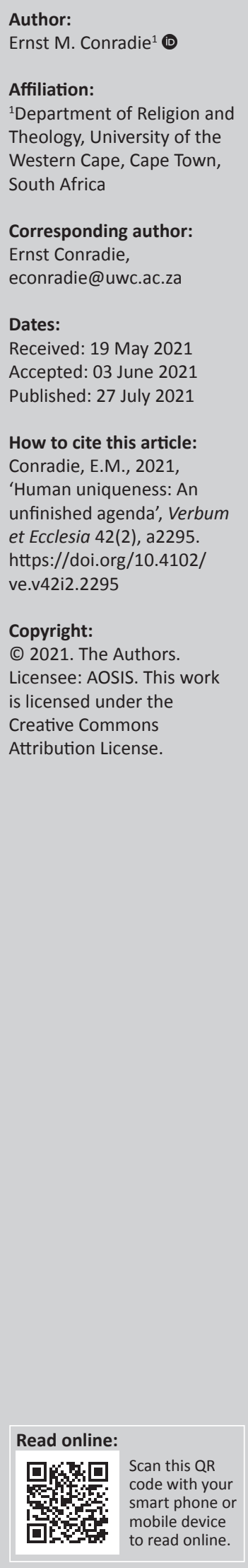

This contribution is structured in the form of a letter to Van Huyssteen focussing on his magnum opus, Alone in the World? (2006). It recognises, with Van Huyssteen, the danger of docetic detachment and scientific reductionism. It suggests that what is at stake in debates on human uniqueness is a defence of human dignity, human rights and human responsibility. It points to a dilemma in this regard, namely that affirming the evolutionary continuity of humans with other species as well as human dignity on the basis of human uniqueness is only possible on the basis of a hierarchy of intrinsic worth and not equal intrinsic worth. However, amongst humans, such a hierarchy cannot be sustained given the need to affirm equal human dignity. The underlying problem here is to address the dangers of anthropocentrism, especially in the so-called Anthropocene where humans have become a 'geological force of nature'. Van Huyssteen is challenged to consider the reverse side of the emergence of human uniqueness, namely the emergence of human sin. Are humans unique in this regard too?

Intradisciplinary and/or interdisciplinary implications: The theme of human uniqueness is by definition of multi-disciplinary interest as demonstrated in the work of Wentzel van Huyssteen. This contribution highlights an unresolved anthropocentrism, especially in the context of what is termed the 'Anthropocene', that is also of significance within multiple disciplines, including Christian theology and discourse on theology and science.

Keywords: Anthropocene; Anthropocentrism; detachment; human dignity; human uniqueness; image of God; reductionism; sin; Wentzel van Huyssteen.

\section{Preface}

This contribution is structured in the form of a letter to Van Huyssteen focussing on his magnum opus, Alone in the World? (2006). The format of an academic letter allows for more personal and more direct but still critical engagement whilst the academic distance of a discursive argument may inhibit one to come straight to the point. In the relatively small guild of South African theology, such a direct engagement with each other seems to be both possible and given various divides much needed.

\section{Dear Wentzel}

We don't write proper letters any more, mostly just quick emails. Our colleague Dirk Smit is an exception because he occasionally writes these long, in-depth emails, often saying that he is too busy to answer properly! Not writing letters comes as a loss, I think, because a personal letter allows for engagement with each other as a person and on that basis with one another's work in a way that discursive articles don't. I am very worried that theologians in South Africa have become too afraid to engage critically with each other - probably fearing that theological differences would be framed in terms of issues of race, gender and Eurocentrism.

One of my most precious possessions is a set of hand-written letters between David Bosch and my father (Conradie, [1958] 11 April 1932 - 04 October 1966), starting from a time when Bosch was based in Madwaleni and my father in Matatiele. It was a volatile time with Verwoerd's rise to power, backed by the very Dutch Reformed Church from which both were 'missionaries'. What impressed me the most is the academic depth (often based on exegesis of the Greek text) of their exchange. Oddly, my father always addressed Bosch as 'oom' even though their age difference was less than three years. You have been a father figure for many of us seeking to relate the Christian faith to other forms of knowledge. But don't worry, I won't address you as 'oom'!

I have found that writing letters of an academic kind sometimes enables me to articulate things better. In one volume, I wrote letters to John Calvin, Herman Bavinck, Karl Barth, Oepke Noordmans,

Note: Special Collection: Festschrift for Wentzel van Huyssteen 
Arnold van Ruler, Jürgen Moltmann and several of my teachers. ${ }^{1}$ I also tried that once with Steve de Gruchy (after his death) ${ }^{2}$ and recently also with his father John. I am copying to John, ${ }^{3}$ knowing that he is a friend of yours and because I want to make South African cross-references between your work on human uniqueness and his work on Christian humanism, together with Desmond Tutu's understanding of ubuntu (see Battle 1997), Maimela's (1991) black anthropology, Denise Ackermann's (1998) emphasis on embodied practice and my work on an ecologically rootedanthropology (2005).

I want to thank you once more for encouraging me to submit a book proposal to Ashgate that led to An Ecological Christian Anthropology: At Home on Earth? That book came out in 2005, a year before your Alone in the World? Nevertheless, I borrowed heavily from your discussion of three notions of being the image of God as you published an earlier version of your argument in a volume edited by Cornel du Toit ${ }^{4}$ - which helped me much in gaining some clarity in this regard.

I want to pick up the conversation with you on what I regard as the unfinished agenda of theological reflection on human uniqueness. In the process, I will engage with you on how you explain your own subsequent research agenda, for example, in your 2016 Heyns lecture..$^{5}$ Whatever, anyone has to say on human uniqueness has to build on your argument, but that cannot be the final word for specific reasons that I will explain below. (As an aside, I was recently asked to review a monograph Saving the Neanderthals: Sin, Salvation and Hard Evolution by McCleod-Harrison [2020].) He raises some interesting if speculative questions on whether Neanderthals are included in the story of sin and salvation and whether Jesus could have saved sapiens had he been born as a Neanderthal. He discusses human uniqueness at length and in relation to the image of God. To my surprise, there is no reference to Alone in the World?!)

\section{Contra reductionism and detachment}

As I read your argument in Alone in the World? and the rhetoric embedded in that, I think we both recognise the dual dangers of detachment on the one hand and of reductionism on the other. (These are by the way not the same as the dual dangers of objectivism and relativism that you also recognise and with which I concur.) Detachment (a docetist 'pulling things up') here refers to an idealist (?) detachment from our hominin, mammalian and animal rootedness. You would add that human cognitions are rooted in evolutionary epistemology (so that there are biological constraints on cultural evolution whilst culture is not reducible to biological entities - p. 98), whilst I would add an ecological rootedness, namely in that which natural, material, bodily and earthly. What is at stake is nothing less than the connection amongst the subject matter

1.See Conradie 2013.

2.See Conradie 2012.

3.See Conradie 2019b.

4.See Van Huyssteen 2000

5.See Van Huyssteen 2017 of science, philosophy, the arts and religious studies. This seems to be your main concern, namely to resist an overly abstract notion of human uniqueness, that emerges as it were from nowhere, floating free above nature and the human body (p. 214). Instead, science, art, religion and the like rely on psychological processes enabled by the cognitive fluidity of the human brain so that notions of human uniqueness need to be fully embodied. That emphasis on earthy, embodied and therefore vulnerable humanness lies at the core of your argument - which I support whole-heartedly.

Reductionism, on the other hand, is the danger of pulling everything down, reducing higher levels of complexity to its constituent parts, as if what is aesthetic, ethical and religious can be explained in terms of dialectic material processes (Marx), genes (Dawkins) or algorithms (see Pinker [2018], Harari [2017]). I share your appreciation for the role of selforganisation and emergence in accounting for such complexity. In Holmes Rolston's vocabulary, the value richness (instead of value superiority - p. 43) of being human need not be and should not be devalued. It enables a cultural transfer of information that is much faster than genetic transformation (p. 99). Genes do not hold culture on a leash (p. 266) although the laws that govern lower levels of complexity still apply at higher levels of complexity (as George Ellis or Bob Russell would add). ${ }^{6}$ In your vocabulary, there may be only a $1 \%$ difference (or so) between human and chimpanzee deoxyribonucleic acid (DNA) but that makes all the difference. I remember one of your talks in Stellenbosch where you with some poetic flourish added that chimps don't create symphony orchestras, establish universities, hold regular democratic elections or organise Olympic Games - or something like that. One may add the role of art, technology, religion and science (p. 42). Someone else added that there is a huge difference between a bucket that holds water and one with a $1 \%$ leak. In short, then, one can make too much or too little of that $1 \%$. Rhetorically, it depends on with whom one is talking to whether one would put the emphasis on the one or the other. Perhaps, we need to revisit the 99 sheep in Luke 15:1-7 here.

Quite much hangs on that $1 \%$ ! In my vocabulary, we need that $1 \%$ in order to distinguish between household pets and household pests, between children, chickens and chickpeas. Why else would societies condone eating chickens but not human children? Or, why would vegans denounce eating chickens (given something like $70 \%$ similarity in DNA) but accept eating chickpeas? Indeed, the underlying tensions become evident especially in food arrangements. Don't you think that you made too little of Genesis 1:29-30, following the imago Dei in 1:27 and the dominium terrae in 1:28?

In conceptual categories, I think one may say that there are three crucial contemporary convictions that depend on the $1 \%$ constituting human uniqueness, namely human dignity, human rights and human responsibility. This is the 'ethical thrust' that you recognise along with Shults (2003:142, also 274). Both human rights and human 6. See Ellis and Murphy 1996, Russell. 
responsibility are based on a (Kantian) appreciation of human dignity. Whilst (human) distinctiveness can still be graded in terms of value richness, human dignity can precisely not be graded. All human beings have equal dignity - at least before the law if of course not in practice (where we have VIPs and other 'dignitaries'). Such equal human dignity relies on genetic similarity amongst humans, all belonging to the same species - which serves as a counter to racism, patriarchy and Eurocentrism. Likewise, all human beings embody the image of God (p. 120), including the senile, comatose and severely handicapped. Maybe Neanderthals too? And Homo naledi?

But as you know, human dignity is a slippery concept, especially once one (more precisely legal experts) asks why humans have such dignity? Michael Welker (2001) helped me to see that once one addresses this question, human dignity seems to become a chiffre, a shifting image. The Abrahamic faiths have no problem here as they can draw on the religious notion of the image of God to uphold such dignity. This is in a way funny because human dignity serves as a secular translation of the imago Dei but such dignity can hardly be defended (except as a form of social contract that can be renegotiated) without its underlying religious assumption. What you recognised, perhaps better than anyone else, is that each of these three categories, and indeed the imago Dei itself, depend on a sense of human distinctiveness. Of course, each specimen of each and every species is distinctive so that you use the stronger term human uniqueness. This poses some difficulties in defending a concept of uniqueness with the danger of underestimating the $99 \%$. I will come back to that. One may also use the term 'special' but that smacks of favouritism, even divine election (I know that you would not go there!).

You naughtily used the adverb 'alone' to ask whether humans are 'Alone in the world?' That is naughty not because it is so lonely. As you often joke, the title is not 'Alone in the universe?' We are not that lonely! It is a catchy title but indeed naughty because it suggests some detachment that can easily lead to separation, even alienation from the rest of the 'earth community' (Rasmussen's term 1996), thus underplaying the $99 \%$. Or, was that perhaps your polemical reason for choosing the term and adding the question mark?

\section{What, then, makes humans not only distinctive but unique?}

You have helped all of us working in the sub-disciplines of Christian theology to digest the scientific discussions of this question in fields such as evolutionary biology, animal ethology, palaeoanthropology, evolutionary psychology or, better, the broad range of cognitive sciences. We are all in your debt here and this has helped our mutual colleagues and friends such as Celia Deane-Drummond, Andrew Robinson, Christopher Southgate, Danie Veldsman, myself and surely many others to take on the baton to explore the material on our own and to take this (the continuities and discontinuities with other animals) in different directions.
You rightly warn against attempts to locate human uniqueness in any one human trait. The same apply to substantialist views on the image of God. Time and again continuities between humans and other species have emerged that undermine claims to human uniqueness. For me, the insights emerging from animal ethology regarding forms of proto-morality and even proto-religion (a sense of awe) are especially striking. I understand that you are working on another major book on the evolution of morality and look forward to what you have to say in this regard. Nevertheless, as you describe in some detail, there is an emerging consensus that if anything, it is symbolic consciousness that sets humans apart from other animals and hominins. Chimpanzees, gorillas, dolphins, elephants and some birds have an ability to recognise themselves as individuals and therefore a form of self-consciousness but not symbolic consciousness. You add that humans experience guilt, shame and pride (p. 36) but that may apply, albeit in anthropomorphic categories, to dogs, chimps and horses too. For me, the remarkable books by Terence Deacon, especially The Symbolic Species (1997) and Incomplete Nature (2013), together with the oeuvre of Frans de Waal, have been particularly helpful. I am sure you will agree. I was a visiting scholar at Columbia Theological Seminary in 2016 when Frans de Waal gave a lecture there. ${ }^{7}$ We had lunch together and he then affirmed what he wrote in Are We Smart Enough to Know How Smart Animals Are? (2016), namely that there is nothing like symbolic language evident in other species (also p. 190). More precisely, other animals have the ability to employ icons and more abstract indices but not symbols. With Jablonka and Lamb (2014) (what a remarkable book!), you recognise four dimensions of variation in evolution: genetic, epigenetic, behavioural and symbolic. As you rightly argue (in your Heyns lecture), at least because of the UpperPaleolithic, 'anatomically modern humans crossed a new cognitive threshold into a semiotic realm, a threshold of semiotic competence that allowed for the combination of remarkable new forms of symbolic communication' (see pp. 217-270). If theories of niche construction hold (the third wave of evolutionary biology after Darwin and the neoDarwinian synthesis), there is room for you to recognise (in conversation with Celia Deane-Drummond and Agustin Fuentes) the impact of symbolic behaviour and therefore culture on human evolution.

You are surely correct in sensing that such symbolic consciousness enables language, imagination and creativity and is a necessary presupposition for the emergence of moral reasoning, wisdom and religious behaviour (p. 189). I would add that this also enables human sin: humans are not unique in an ability for wrongdoing or even a form of moral awareness, but if sin is understood as the privation of the good, epitomised by a broken relationship with the triune God, then this may well constitute human uniqueness of a different kind. The refusal to accept our finitude (p. 304) is one manifestation of sin (as pride), but as I argued in 7.For a conversation with De Waal on human sin, see Conradie $2017 a$. 
Redeeming Sin? (2017b), not the only one. (I also discuss anthropocentrism [again pride], consumerism [greed], moral failure [sloth], alienation, domination and folly.)

You helped us to understand such emerging scientific consensus more clearly. It is striking that scholars in such scientific disciplines have given you credit for understanding their insights well. Maybe you have even understood them better than they understand themselves! As you recognise, you probably did not and could not contribute to the discussion in scientific terms. To make a distinct contribution, you had to do so as a theologian. This is where your discussion on the image of God is so important. I have used your distinction amongst substantialist, functionalist and relational approaches to the image of God (see p. 126) already in An Ecological Christian Anthropology and do so regularly in teaching as well. Your critique of substantialist views is trenchant: it is not only scientifically questionable but also tends to denigrate what is physical (p. 134). There is no one fixed feature or human ability that could constitute the image; if anything, it is our adaptability and versatility that set us apart (p. 268). You also appropriately refer to the feminist and ecological critiques of functionalist views given their underlying androcentrism and anthropocentrism (p. 135). One may even claim some emerging consensus that a relational notion of the image is relatively more adequate than the others. My colleague Vaai (2017) from Fiji, with his stress on an ecorelational approach, will surely agree.

For me, it helps to gain a more strictly theological (for some a Christological) interpretation. Imago Dei can best be understood as imitatio Dei (p. 274). Inversely and ironically, it is in constructing notions of God that we can uncover what being human entails (p. 282). So, Calvin had a point in saying that knowledge of the self and knowledge of God are deeply intertwined. Indeed, if we are created in the image of God, the identity and character of this God matter. We cannot talk about human nature apart from God's nature, also revealing the inadequacies of our notions of God (p. 118, 283). We need to tone down all those 'omni-' characteristics in order to retrieve that this is a God characterised by mercy and therefore justice (Welker 1994), a God of love or, as Arnold van Ruler would have it, ${ }^{8}$ a God of joy who had fun in creating and finds joy also in somewhat cockeyed, funny creatures. I note that you are not too keen to move such an abstract emphasis on relationality towards communion within the social Trinity (p. 154), mainly because it tends to isolate theology from multi-disciplinary discussions. I can only concur.

I wonder whether you would also agree that a relational notion of the image does not imply that a substantialist or a functional view can be readily abandoned, only that it becomes chastened. Given the need to stress human responsibility, we cannot come away from functional views, typically associated with dominium terrae, even if most 8.For a discussion, see especially Van Keulen 2009. images for such responsibility (e.g. dominium, stewardship, priesthood, even partnership) remain problematic. Middleton's (2005) notion of a wise and generous artisan (p. 157) is certainly more attractive than most others. Hefner's notion of 'created co-creators' (which you seem to like but I don't - p. 148) also remains focussed on the functional human task (or 'factor').

That a substantialist element cannot be abandoned becomes especially clear when one reflects on the nature of such a relationship and on the relata. Interestingly, this is also recognised by Berkouwer (1962:138) who describes that relationship in terms of the biblical image of being God's children. Did you learn that from him whilst you studied at the VU? Or, perhaps from Van Selms who described the universe as God's child, an image more recently picked up by Fensham (jr 2012)? If so, being the image of God (better living in the image of God) assumes but cannot be reduced to symbolic consciousness or exocentricity (see p. 140) - which are human capabilities and thus remain substantialist, even if directed towards human fellowship with God as our gift and our destiny (Pannenberg 1985). The same applies to Jenson's (1995) notion of the praying animal to whom (and not only about whom) God speaks. This is possible either because of human capabilities or because of God's anthropocentric favouritism. (Surely God the gardener speaks to her plants as well?) It would not do to describe this relationship as one of love (p. 147) because God's love extends to the whole cosmos so that there is nothing special about being human in this regard. I warm to eschatological notions of the image (see p. 143) mainly because that gathers together the fragments 'under one head'. This is where theologians can, I think, add value to multi-disciplinary discourse on human dignity.

In my assessment, such crucial insights on relationality do not resolve the underlying problem evident in substantialist views. Surely, God has a relationship with all creatures, so what is then different about God's relationship with humans? Fearing detachment, one may again underplay such differences, for example, by stressing a notion of deep incarnation - as your friend and co-author Niels Gregersen (2015) and the late Denis Edwards (2015) would surely suggest. One may also suggest that being the image of God is not something exclusively human, but that the image of God serves as a paradigm for the whole evolutionary lineage behind the emergence of humanity and therefore of the integrity of God's whole creation. Human dignity is not inversely proportioned to the intrinsic worth of other forms of life, as if one has to underplay such worth in order to emphasise human dignity or vice versa (seeing this as a seesaw where one must go down if the other goes up). ${ }^{9}$ I first learned this from De Lange (1997) in his Gevoel voor Verhoudingen. This would allow one to stress the intrinsic worth of all forms of life as created by God. Such intrinsic worth would capture something of the (mostly mammalian) 9.See Conradie 2004. 
'solidarity of the sixth day' (Helmuth Thielicke) between landed creatures (see p. 156), but also the (evolutionary) continuity with the third day (plants) and the fifth day (fish, birds).

But does such an affirmation of intrinsic worth also imply equal intrinsic worth? I thought that you would say 'No!' to that, but you come close to saying 'Yes' by calling for a notion of the imago Dei emerging from nature itself, one that does not imply any superiority or a greater value over other animals or earlier hominids' (p. 215), whilst still appreciating an embodied human personhood. In a summary statement in Alone in the World? you add:

[T] his obviously implies that we cannot afford to think of human distinctiveness in terms of value superiority over other animals, or over the rest of nature, nor conceive of ourselves in a superior, disembodied position at the 'center of the universe.' Rather, the evidence compels us to revision the notion of human uniqueness solely in terms of species specificity and concrete embodiment. (pp. 271-272)

OK, so no value superiority over Neanderthals or Homo naledi! But I presume that you would condone the compassionate slaughtering of turkeys for Thanksgiving (thanks for that dinner at your house in 2008!), but not slaughtering a human child for Christmas?

Some adopting a biocentric approach and most deep ecologists would indeed say 'Yes' to equal intrinsic worth. This then calls into question contemporary food arrangements. Everyone draws a line somewhere on equal intrinsic worth. Meatatarians (a naughty term that Danie Veldsman may use to legitimise a South African braai) would distinguish between eating humans and eating other animals. Utilitarians (like your Princeton colleague Peter Singer) may draw the line with the ability to experience pain. Some vegetarians would avoid eating anything with eyes. Piscatarians would nevertheless say that this excludes fish. Fruitarians would defend the rights of all living plants, denounce murdering carrots and eat only seeds of already dead plants, nuts and fruit. Some would condone eating milk products, honey and (unfertilised) eggs because it does not entail 'murder', but others would reply that the eighth commandment on stealing is as weighty as the sixth commandment on murder. In short, if with MacIntyre (1999), we are vulnerable and dependent animals (see p. 284), this is epitomised by our embodied need for food that also connects us most intimately to other forms of life. Eating is even more intimate than sexual intercourse ... Indeed, what on earth are we doing when we eat? ${ }^{10}$

Despite all these controversies, it seems that a qualitative distinction (in kind, not only in degree) amongst minerals, plants, animals and humans remains valid, a distinction defended by Jonas (1966) in his profound The Phenomenology of Life (have you read that?). I also found that in Michel Serres' recent work on Hominescence (2019). This is where Holmes Rolston's notion of value richness may again be helpful. ${ }^{11}$ 10.For a discussion, see Conradie 2016a, 2016b, 2019 a.

11.See Rolston 1988, 1999, 2010.
There is no need to deny value richness as long as this is balanced with instrumental value (a guide dog has more instrumental value to the blind person than vice versa) and systemic value (grass has more systemic value than cows grazing on the grass). Nevertheless, the question remains what criteria for value richness may be employed. Do such criteria not remain all too often anthropocentric? This is where substantialist notions of the image of God slip through the back door, namely to locate such value richness in, for example, moral awareness (of what ought to be), symbolic consciousness (with added layers of reference), aesthetic sensibility (of what is attractive), creativity or whatever else for you expressed also and especially in religious imagination (see p. 240). Once this becomes graded, a deeper problem emerges, namely why such criteria are not applied amongst humans too. Why is human intrinsic worth then not to be graded as well? Why do humans have equal dignity? Again, in practice, human dignity is graded but this opens a Pandora's box filled with Eurocentrism, racism, androcentrism and intellectual elitism. Interestingly, this problem also surfaces in transhuman debates, given the fear that artificially enhanced humans will look down on the rest of us and treat us as our ancestors treated the indigenous people of southern Africa.

I think we have a real conceptual Catch 22 here. It is posed by the significance of that $1 \%$ and is not readily resolved. My sense is that you intuitively but also explicitly recognised exactly what is at stake in asking questions about human uniqueness. Your conclusion is I think fair enough, namely that the imago Dei should be understood as emerging from nature itself (which you argue for at length and what the next generation may well take for granted) that the whole of nature need not therefore be seen as created in the image of God (given human uniqueness) and that the imago Dei is, therefore, limited to Homo sapiens (p. 322).

Of course, it would be pretentious to say that you or anyone else could resolve this problem, but we remain in your debt for articulating the debate on human uniqueness so clearly and in conversation with other disciplines. I would be keen to hear what you think of my own tentative proposal in $A n$ Ecological Christian Anthropology, namely to defend an ecocentric approach: what is perceived to be good for the 'whole' (subject to the social construction of reality) overrides (I almost wrote Trumps) the perceived interests of any one species, group or specimen. This is dangerous, as the critique of environmental fascism also suggests. However, I think we also need to allow for some intraspecies rules. This is where a social contract (for Serres [1995] including a natural contract), especially the content of that contract, becomes important again. Affirming equal human dignity is such an intra-species rule, one that is already present in the Hebraic imagination, is epitomised in the ministry of Jesus of Nazareth, forms the basis of any constitutional democracy and remains crucial for human survival, perhaps increasingly so amidst looming threats in the Anthropocene. 


\section{An unfinished agenda regarding anthropocentrism}

I was pleased to see that you discussed the problem of anthropocentrism in Alone in the World?, drawing on Michael Welker's (see 1999) and his Doktorvater Jürgen Moltmann's critique of a destructive functionalist view of the image of God (p. 150). The problem is that we are still stuck between an arrogant, anthropocentric legitimation of human privilege, based on human uniqueness, and all too romantic notions of being dialogue partners, friends (McFague 1987), co-workers and even co-creators with God (Hefner 1993:148). Your discussion of these positions is excellent and helps us to guard against all these dangers. Your question, 'Could we revision the idea of dominium terrae without a power-centered and violent anthropocentrism?' (p. 155) is exactly to the point. But where do we go from there to address contemporary challenges?

We may all agree on the need for a critique of white supremacy, androcentrism and heteronormativity, but this does not yield by itself a constructive anthropology. Questions abound! For example: So, what is the ecological significance of human distinctiveness? How does that add value within the earth community? Who are the victims of an emphasis on human uniqueness? Put differently, mimicking John Rawls, how does inequality benefit the system as a whole, including those who are least privileged? Inequality cannot and need not be eliminated but that should then be for the sake of the vulnerable (as in feeding infants). Moreover, what does it mean to be human in the age of humans, that is, in the Anthropocene, where the impact of human destructiveness has become geological in scope? Who is this anthropos? Are we not still making generalised assumptions about this anthropos that hides his all too male, fairly affluent, often consumerist, Caucasian identity? Clearly, claims to human distinctiveness matter and are exacerbated by domination in the name of difference amongst humans. This has now become a 'geological force of nature'. This makes one wonder: What on earth is wrong with the world?!

The problem as I see it is that none of the available alternatives are viable or attractive. We may agree that modernism with its notion of being 'Masters of the Planet' (as per the title of a book by your friend Tattersall 2012) cannot be maintained. But where do we go from here? The other available options include a return to Renaissance humanism (for John de Gruchy Christian humanism), or to African humanism (Desmond Tutu and many others) or a rejection of modernism in the name of deep ecology with its dissolution of the human self in an oceanic, even cosmic Self, other forms of posthumanism or even transhumanism, or an ecological retrieval of modernism through ecomodernism or Hamilton's (2017) suggestion of a 'new anthropocentrism' in Defiant Earth (2017 - a must read). Haraway (2017) thought that humans are best understood as compost (humus), entangled with other species, but I wonder whether humans, if compared with earth worms, are any good at doing that. Can you think of other alternatives? It would surely be disingenuous to suggest that the Bible or the Christian faith offers a way forward. At best, doctrine typically helps to guard us against and guide us between extremes, often between contrasting heresies, for example, between anthropological docetism and reductionism. The biblical texts, likewise, avoid the extremes of thinking too lowly of being human (nothing but dust of the earth, allowing one to treat others as dust) or too highly (little less than angels, allowing a legitimation of human arrogance).

So, Wentzel, there is an unfinished agenda here and I want to challenge you to return to the implications of human uniqueness. At the very end of Alone in the World?, you recognised the need for Christian theology to explore issues that are crucial for understanding human uniqueness (p. 325). You mention the realities of vulnerability, tragedy and affliction, the distinctions of good, evil, moral failure and sin, and the possibilities of hope, redemption and grace. What I am suggesting is that with the advent of the Anthropocene, the stakes are now higher than ever before. You did some of the ground work in seeing humans as emerging from nature itself but what you only hinted at is now the main agenda, namely where humans (or at least some humans, readily imitated by others) have turned against the rest of nature. Put differently: How could human evolution, including the ethical project (Kitcher 2011) or the evolution of morality, compassion and wisdom, have gone so horribly wrong? This is the inverse of talk about human uniqueness. Are we humans perhaps unique in our ability to $\sin ?^{12}$ Or, could we blame that on our pre-human evolutionary ancestors (and thus on the snake!)?

You do touch on the theme on sin and the fall of humanity in Alone in the World? (e.g. pp. 127-131, 304-307), but I think it is fair to say that your focus is on the positive aspects of human uniqueness, especially the cave art of the Cro-Magnons. What is weird to me is that despite the vehement critique of the fall of humanity as in some way a historical event (or process) from the point of evolutionary biology, in secular discourse on the Anthropocene, this question re-emerged given the need to mark the start of the Anthropocene as exactly as possible, even with a 'golden spike'. There is quite some controversy here: Should the golden spike be placed with the start of the 'great acceleration' after 1945, or with the first nuclear explosion at Alamogordo, New Mexico on 16 July 1945, or in 1776 with James Watt and his steam-engine as marking the industrial revolution, or with mercantile capitalism, or with the 'Orbis Spike' around 1610 marking the 'Columbian exchange' and the impact of imperialism and colonialism, or much earlier with the agricultural revolution or even earlier with the devastating impact on megafauna following the global spread of Homo sapiens? For a discussion, see my Secular Discourse on Sin in the Anthropocene (Conradie 2020b).

12.See Conradie 2017a, 2017 b, also 2020 a. 
Do you see where I am going with this? Where did things start going wrong in human history - if compared with the history of other destructive species. With niche construction? With tool-making? With the increasing complexity in the way we interface with the world? The cultural awakening? The use of symbols and language? With 'rapidly evolving human cognition and social structure that require increased cooperative capabilities and coordination within human communities' (your formulation in the 2016 Heyns lecture)? The shift to agriculture (Cain!)? With urbanisation? The violence prompted by hoarding produce - as your friend Agustin Fuentes suggested to me? ${ }^{13}$ Surely, this was a process (of 'falling', even whilst 'falling upwards?'), but it does matter to assess the impact of each of these. The humanist (often atheist) alternative is to speak of the world as gradually becoming a better place because violence has allegedly declined - as Stephen Pinker (2011) controversially argues. Even Kitcher's ethical project seems to assume that the emergence of a richer conception of the good continues and that progress with ethical problem-solving can follow the path of scientific progress. Is this not some form of 19th century or 1960s optimism, a belief in ethical progress, continued in the false hope for a 'good Anthropocene?' What implications follow for your research agenda of making progress with problem-solving in theological reflection?

What do you make of all this, Wentzel?

\section{Singing along, not alone}

As you are so fond of music (anything but Wagner please!), let me offer you one other suggestion also derived from the first creation narrative in Genesis. When I first encountered Moltmann's discussion on the Sabbath as an ecological motif, I was deeply impressed. ${ }^{14}$ I wrote Rus vir die Hele Aarde (1996) in response, but hardly followed my own advice ever since. (Neither did you, by the way.) The Sabbath is the Feast Day of creation. It forms the climax of the first creation story, oddly placed in chapter 2 of Genesis. What is so striking is that it is not one species that forms the 'crown' of creation but the peaceful co-existence (convivencia) of all creatures in the presence of the Creator. The day of rest is a source of joy, praise, fun, love, inspiration, creativity for all concerned. Of course, such rest can hardly be found anywhere in evolutionary history - or in human history. It is, therefore, best understood as an eschatological and not a primordial symbol - that violent conflict, predation, biting, chewing, digesting each other do not have the final word. If so, human uniqueness may be best understood not in terms of what distinguishes us from other animals but in our anticipation of the relatedness of all creatures. This needs to be qualified as predators, racists and enemies are also intimately related to their polar opposites. The more racist one becomes, the more one's self-understanding is shaped by those whom one detests. It is not about relationality per se but about the nature of such relationships. This is how I, following my own father's thesis, see love, namely not as a disposition of a 13.See Fuentes 2017. subject or an agent, nor a form of selflessness or altruism (contra sociobiologists), but as a characterisation of the quality of relationships, with the connotations of mutual respect, reciprocity (being willing to receive and to give), desiring each other (eros), finding joy in each other's intimate presence. Equality is not required for a relationship of love as the examples of parents and children, teachers and students, a coach and team members, Creator and creatures suggest.

Once we gain a glimpse of the Sabbath rest, we can join in the hymn of praise for the Creator and the exuberant song of creatures interacting with each other (enjoying, competing, interjecting, mocking, joking, humming or whatever). We humans do not have copyright on that song, but we can tune in on the cacophony of loeries, frogs, wolves, jackals and whales, even cockroaches and bees (if not mosquitoes which makes me inclined towards the notion of a cosmic fall!). For that to become possible, we will need to be moved by God's Spirit beyond Silent Spring (the absence of birds) and Silent Night (the absence of frogs) ${ }^{15}$ to sing the Lord's song in a strange, strange land.

Suffice it to say, Wentzel, that I am very pleased about the question mark in the title of Alone in the World? One can sing all by oneself in the shower, but singing along in the world rather than alone in the world sounds so much better, don't you think? It assumes an indigenous sense of belonging rather than a (Western?) loneliness.

Wishing you and Hester more good years.

Ernst Conradie

\section{Acknowledgements Competing interests}

The author declares that he has no financial or personal relationships that may have inappropriately influenced him in writing this article.

\section{Author's contributions}

E.M.C. is the sole author of this article.

\section{Ethical considerations}

This article followed all ethical standards for research without direct contact with human or animal subjects.

\section{Funding information}

This research received no specific grant from any funding agency in the public, commercial or not-for-profit sectors.

\section{Data availability}

Data sharing is not applicable to this article as no new data were created or analysed in this study.

15. See Hayes 2017. 


\section{Disclaimer}

The views and opinions expressed in this article are those of the author and do not necessarily reflect the official policy or position of any affiliated agency of the author.

\section{References}

Ackermann, D.M., 1998, 'Becoming fully human: An ethic of relationship in difference and otherness', Journal of Theology for Southern Africa 102, 13-27.

Battle, M., 1997, Reconciliation: The ubuntu theology of Desmond Tutu, Pilgrim Press, Cleveland, $\mathrm{OH}$.

Berkouwer, G.C., 1962, Man: The image of God, Eerdmans, Grand Rapids, MI.

Conradie, E.M., 1996, Rus vir die hele aarde, Lux Verbi, Kaapstad.

Conradie, E.M., 2004, 'On the integrity of the human person and the integrity of creation: Some Christian theological perspectives', in C.W. du Toit (ed.), The integrity of the human person in the African context: Perspectives from science and religion, pp. 107-152, University of South Africa, Pretoria.

Conradie, E.M., 2005, An ecological Christian anthropology: At home on earth? Ashgate, Aldershot.

Conradie, E.M., 2012, 'A distinctly South African way of doing theology? In conversation with Steve de Gruchy', in J.R. Cochrane, E.K. Bongmba, I.A. Phiri \& D. van de Water (eds.), Living on the edge: Essays in honour of Steve de Gruchy, activist and theologian, pp. 17-29, Cluster Publications, Pietermaritzburg.

Conradie, E.M., 2013, Saving the earth? The legacy of reformed views on 're-creation', LIT Verlag, Berlin.

Conradie, E.M., 2016a, 'What do we do when we eat? Part 1: An inconclusive inquiry', Scriptura 115, 1-17. https://doi.org/10.7833/115-0-1291

Conradie, E.M., 2016b, 'What do we do when we eat? Part 2: A theological inquiry', Scriptura 115, 1-19. https://doi.org/10.7833/115-0-1293

Conradie, E.M., 2017a, 'Do only humans sin? In conversation with Frans de Waal', in M. Fuller \& D. Evers (eds.), Are we special? Science and theology questioning human uniqueness, pp. 117-135, Springer, Heidelberg.

Conradie, E.M., 2017b, Redeeming sin? Social diagnostics amid ecological destruction, Lexington Books, Lanham, MD.

Conradie, E.M., 2019a, 'Could eating other creatures be a way of discovering their intrinsic value?', Journal of Theology for Southern Africa 164(1), 26-39.

Conradie, E.M., 2019b, 'Is Christian humanism what is needed in the age of the Anthropocene?', Stellenbosch Theological Journal 5(3), 41-58. https://doi. Anthropocene?', Stellenbosch
org/10.17570/stj.2019.v5n3.a02

Conradie, E.M., 2020a, 'The project and prospects of "redeeming sin?": Some core insights and several unresolved problems', Scriptura 119(2), 1-22. https://doi. org/10.7833/119-2-1689

Conradie, E.M., 2020b, Secular discourse on sin in the Anthropocene: What's wrong with the world?, Lexington Books, Lanham, MD.

Conradie, P., 1958, 'Die struktuur van die liefde', M.A. thesis, University of Stellenbosch.

Deacon, T.W., 1997, The symbolic species: The co-evolution of language and the brain, W.W. Norton, New York, NY.

Deacon, T.W., 2013, Incomplete nature: How mind emerged from matter, W.W. Norton, New York, NY.

De Gruchy, J.W., 2006, Confessions of a Christian humanist, Fortress, Minneapolis, MN.

De Lange, F., 1997, Gevoel voor verhoudingen: God, evolutie en ethiek, JH Kok, Kampen.

De Waal, F., 2016, Are we smart enough to know how smart animals are?, W.W. Norton \& Company, New York, NY.

Edwards, D., 2015, 'Incarnation and the natural world: Explorations in the tradition of Athanasius', in N.H. Gregersen (ed.), Incarnation: On the scope and depth of Christology, pp. 157-176, Fortress, Minneapolis, MN.

Ellis, G.F.R. \& Murphy, N., 1996, On the moral nature of the universe: Cosmology, theology, and ethics, Fortress, Minneapolis, MN.

Fensham, C., 2012, 'The sacrament of the first child of God: A renewed Christian eco-imaginary', Scriptura, 111, 323-332. https://doi.org/10.7833/111-0-16

Fuentes, A., 2017, The creative spark: How imagination made humans exceptional, Penguin, New York, NY.

Gregersen, N.H. (ed.), 2015, Incarnation: On the scope and depth of Christology, Fortress, Minneapolis, MN.

Hamilton, C., 2017, Defiant earth: The fate of humans in the Anthropocene, Polity Press, Cambridge.
Harari, Y., 2017, Homo deus: A brief history of tomorrow, Vintage, London.

Haraway, D.J., 2017, Staying with the trouble: Making kin in the Chthulucene, Duke University Press, Durham.

Hayes, T., 2017, 'From silent spring to silent night: Agrochemicals and the Anthropocene', Elementa: Science of the Anthropocene 5, 57. https://doi org/10.1525/elementa.246

Hefner, P., 1993, The human factor: Evolution, culture and religion, Fortress, Minneapolis, MN.

Jablonka, E. \& Lamb, M.J., 2014, Evolution in four dimensions: Genetic, epigenetic behavioral, and symbolic variation in the history of life, MIT Press, Cambridge.

Jenson, R.W., 1995, 'The praying animal', in Essays in theology and culture, pp. 117-131, Eerdmans, Grand Rapids, MI.

Jonas, H., 1966, The phenomenology of life: Towards a philosophical biology, Northwestern University Press, Evanston, IL.

Kitcher, P., 2011, The ethical project, Harvard University Press, Cambridge.

MacIntyre, A., 1999, Dependent rational animals: Why human beings need the virtues, Duckworth, London.

Maimela, S., 1991, 'Traditional African anthropology and Christian Theology', Journal of Theology for Southern Africa 76, 4-14.

McCleod-Harrison, M., 2020, Saving the Neanderthals: Sin, salvation, and hard evolution, Lexington Books, Lanham, MD.

McFague, S., 1987, Models of God: Theology for an ecological nuclear age, Fortress, Philadelphia, PA.

Middleton, J.R., 2005, The liberating image: The imago Dei in Genesis 1, Eerdmans, Grand Rapids, MI.

Moltmann, J., 1985, God in creation: An ecological doctrine of creation, SCM Press, London.

Pannenberg, W., 1985, Anthropology in theological perspective, T. \& T. Clark, Edinburgh.

Pinker, S., 2011, The better angels of our nature: Why violence has declined, Viking, New York, NY.

Pinker, S., 2018, Enlightenment now: The care for reason, science, humanism and progress, Penguin, London.

Rasmussen, L.L., 1996, Earth community earth ethics, Orbis, Maryknoll, NY.

Rolston, H. (III), 1988, Environmental ethics: Duties to and values in the natural world, Temple University Press, Philadelphia, PA.

Rolston, H. (III), 1999, Genes, genesis and God, Cambridge University Press, London.

Rolston, H. (III), 2010, Three big bangs: Matter-energy, life, mind, Columbia University Press, New York, NY.

Russell, R.J., 2008, Cosmology from Alpha to Omega: The creative mutual interaction of theology and science, Fortress, Minneapolis, MN.

Serres, M., 1995, The natural contract, transl. E. MaxArthur and W. Paulson, The University of Michigan Press, Ann Arbor, MI.

Serres, M., 2019, Hominescence, Bloomsbury, London.

Shults, F.L., 2003, Reforming theological anthropology after the philosophical turn to relationality, Eerdmans, Grand Rapids, MI.

Tattersall, I., 2012, Masters of the planet: The search for our human origins, Palgrave Macmillan, New York, NY.

Vaai, U.L., 2017, 'We are therefore we don't have', in U.L. Vaai \& U. Nabobo-Baba (eds.), The relational self: Decolonising personhood in the Pacific, pp. 283-284, University of the South Pacific and Pacific Theological College, Suva.

Van Huyssteen, J.W., 2000, 'Evolution and the human mind: How special are we really?', in C.W. du Toit (ed.), Evolution and creativity: A new dialogue between faith and knowledge, pp. 130-180, UNISA, Pretoria.

Van Huyssteen, J.W., 2006, Alone in the world? Human uniqueness in science and theology, Eerdmans, Grand Rapids, MI.

Van Huyssteen, J.W., 2017, "Is there any hope for "truth" and "progress" in theological thinking today?', Verbum et Ecclesia 38(1), a1792. https://doi.org/10.4102/ve. v38i1.1792

Van Keulen, D.J., 2009, “'We zijn een grap van God”: Van Ruler over de vreugde', in D.J. Van Keulen, G. Harinck \& G. Van den Brink (eds.), Men moet telkens opnieuw de reuzenzwaai aan de rekstok maken: Verder met Van Ruler, pp. 177-191, Boekencentrum, Zoetermeer.

Welker, M., 1994, God the spirit, Fortress, Minneapolis, MN.

Welker, M., 1999, Creation and reality, Fortress, Minneapolis, MN.

Welker, M., 2001, 'Person, Menschenwürde und Gottebenbildlichkeit', Jahrbuch für Biblische theologie 15, 247-262. 